O.O. Matusevych

\title{
METHODOLOGY OF DETERMINATION OF QUALITY INDEX OF MAINTENANCE SERVICE SYSTEM OF POWER EQUIPMENT OF TRACTION SUBSTATIONS
}

Purpose. The purpose of this paper is development of methodology for definition of a quality system of maintenance and repair $(M$ and $P$ ) power equipment of traction substations (TS) of electrified railways operating under conditions of uncertainty based on expert information. Methodology. The basic tenets of the theory of fuzzy sets and marks, linguistic and interval estimates of experts were applied to solve this problem. Results. Analysis of the existing diversity of approaches to development of modern methods of improvement of $M$ and $P$ allows us to conclude that the improvement in the quality of the system is achieved by solving individual problems increase the operational reliability of power equipment of traction substations in the following main interrelated areas. There are technical, economic and organizational. The basis of the quality evaluation system is initial data and expertise developed version of the document formalized quality evaluation of electrical equipment of traction substations by experts. The choice of determining the level of Quality service system based on the marks, linguistic and interval estimates of experts, which are reflected in quantitative and / or qualitative form was done. The possible options for expert data presentation and their corresponding quantitative methods of calculating the integral index of quality improvement system maintenance and $P$ of traction substations were described. The methodology and the method of assessing the quality of system maintenance and $P$ of TS allows quickly respond to changing operating conditions of power equipment of traction substations, and to determine the most effective strategies for maintenance of electrical and P TS under conditions of uncertainty functioning distance electricity. Originality. The method of a systematic approach to improve the quality of the system maintenance and $P$ of power equipment of traction substation under conditions of uncertainty based on expert information was further developed. The author offers a number of options at first time. There are version of the document formalized quality evaluation of power equipment of traction substations by experts; expression to define the integral Quality systems maintenance and electrical power P TS, which is absent in the standard system maintenance and $P$; matrix of quality system with regard to steps (methods) and ways of increasing service quality electrical power control systems. This method makes it possible to conduct an expert assessment of the maintenance system and to predict and select the option rational system of quality improvement and maintenance of power equipment of traction substations considering not only technical but also organizational, legal, financial and economic measures. Practical value. Improvement on electrified railways of Ukraine quality management system maintenance and $P$ TS will improve the efficiency and quality of maintenance of power equipment and provide TA prevent or reduce the severity of possible equipment failures. Based on the relationships matrix components as systems maintenance and electrical power $P$ TP were formed expressions calculating quality indices of integrated systems with directions and stages for specific equipment and systems in general. It was determined that an increase in the quality and maintenance of electrical PR, the rate of change of the measured value at step $k$ during operation is reduced while the standard deviation parameter is also reduced, and the probability of electrical TA increases. References 8, tables 3.

Key words: traction substation, technical condition of equipment, quality system of maintenance and repair, expert information, fuzzy sets, integral indicator of quality.

Целью статьи является разработка методологии определения качества системы технического обслуживания и ремонта (ТО и Р) силового электрооборудования тяговых подстанций (ТП) электрифицированных эселезных дорог в условиях неорределенности эксплуатации на основе экспертной информации. Методика. Для решения поставленной задачи применены основные положения теории нечетких множеств, а также бальных, лингвистических и интервальных оценок экспертов. Результаты. Анализ существующего многообразия подходов к разработке современных методов совериенствования системы ТО и Р позволяет сделать вывод, что решение проблемы повышения качества системы достигается путем решения индивдуальных задач повыщения эксплуатационной надежности силового электрооборудования ТП в следующих основных взаимосвязанных направлениях: техническом, экономическом и организационном. В основу оценки качества системы положены начальные экспертные данные и разработан вариант формализированного документа оценки качества обслуживания электрооборудования ТП экспертами. Проведен выбор определения уровня показателя качества системы обслуживания на основе бальных, лингвистических и интервальных оценок экспертов, которые отображаются в количественной и/или качественной форме. Рассмотрены возможные варианты представления экспертных данных и соответствующие им методики расчета количественного интегрального показателя уровня повышения качества системы ТО и Р силового электрооборудования ТП. Разработанная методика и метод оценки качества системы ТО и Р ТП позволяет оперативно реагировать на изменения условий функционирования силового электрооборудования ТП, а такэе определять наиболее эффективные стратегии ТО и Р электрооборудования ТП в условиях неопределенности функционирования дистанции электроснабжения. Научная новизна. В статье получил дальнейшее развитие метод системного подхода по повыщению качества функционирования системы ТО и Р силового электрооборудования ТП в условиях неопределенности на основе экспертной информации. В этом направлении автор впервые предлагает: вариант формализированного документа оценки качества обслужсивания силового электрооборудования ТП экспертами; выражение для определения интегрального показателя качества системы ТО и $\boldsymbol{P}$ силового электрооборудования ТП, которое отсутствует в стандартах системы ТО и Р; матрицу качества системы с учетом этапов (методов) и направлений повыщения качества обслуживания силового электрооборудования ТП. Данный метод дает возможность проводить экспертную оценку состояния системы обслуживания, прогнозировать и выбирать рациональный вариант повышения качества системы ТО и Р силового электрооборудования ТП с учетом технических, организационно-правовых и финансово-экономических мероприятий. Практическая значимость.

(C) O.O. Matusevych 
Усовериенствование на электрифицированных жселезных дорогах Украины системы управления качеством ТО и Р ТП позволит повысить эффективность и качество системы технического обслуживания силового электрооборудования ТП, а также предупредить возникновение или снизить тяжесть возможных отказов оборудования. На основе взаимосвязей составляющих матрицы качества системы ТО и Р сформированы выражения для расчета интегральных показателей качества системы по направлениям и этапам для конкретного оборудования и системы в целом. Установлено, что при повышении качества ТО и Р электрооборудования скорость изменения измеряемого значения параметра $x_{i}$ на і-м шаге во время эксплуатации уменьщается, при этом среднеквадратичное отклонение параметра б такэке уменьшается, а вероятность Р(t) безотказной работы электрооборудования ТП увеличивается. Библ. 8 , табл. 3 .

Ключевые слова: тяговая подстанция, техническое состояние оборудования, качество системы технического обслуживания и ремонта, экспертная информация, нечеткие множества, интегральный показатель качества.

State of the problems. Topicality. The quality of the system of the maintenance and repair (SMR) of power electrical equipment of traction substations (TS) of electrified railways can be evaluated by the set of different parameters (individual, group, integrated), each of which has a quantitative or qualitative character. Relations between indicators, by which the process of organizing and carrying out SMR of TS is described, have a complex structure. In general, some indicators can be expressed in terms of others who are on the same or different levels of service and model of the process of the equipment service and diagnostics. As the theory and practice of diagnosis show [1, 2], a very common approach to data analysis of the equipment diagnostics is the transition from a certain set of parameters (often single) which values can be easily measured (calculated) in their great quantity, to a small number of integrated indicators which are functionally related to the output ones. The main purpose of the transition from the single set of indicators to group ones, and the last ones to integral is getting the indicators characterizing the integral characteristics of the achieved quality of the SMR and/or its individual components. Evaluation of the SMR of the TS equipment is determined by the degree (fullness) of meeting requirements that apply to the SMR. To perform such an assessment it is necessary to make a formal definition of the task of transformation of quality indicators of the maintenance system components to integral ones.

Analysis of investigations. In the basis of the quality system evaluation we put initial expert data of definition of integrated indicator of the system quality. For the examination an expert group is established and recommendations for the examination are presented [3]. For the purpose of the examination for different types of equipment «the map of the object of examination» is prepared. For example, the author suggests a formalized version of a document of assessment by experts the quality of electrical maintenance of the TS electrical equipment (see Table. 1).

In expert investigations typically they use three types of questions - closed, open and semi-open. In answering closed questions it is possible to select answers only from options pre-defined by questionnaire compilers. In response to an open question the expert opinion in a free manner is presented. Semi-open questions occupy an intermediate position: in addition to the selection from options listed in the map of options estimation, it is possible to add own views and opinions.

Definition of the quality indicator's level of the SMR of the TS may be based on ballroom, linguistic and interval estimates of experts, which are expressed in quantitative and/or qualitative form [3-5]. Scale of the assessments conformity is given in Table. 2 .

The task of the expert committee is to choose the optimal strategy of the SMR. There are two fundamentally different approaches to its solution [3].

The first approach is based on a comparison of existing SMR. For example, each of the experts selects the system according to their reasoning. Obtained from experts ordering (ranking) are processed by various mathematical methods to calculate the final opinion of an expert panel.

The second approach aims to compare the importance of various SMR quality parameters and build integrated quality indicator (rating assessment) by the help of which it is possible to order the considered SMR by quality (to calculate the system's rating).

In this case, for the processing the results of expert assessments and determining the resulting indicators of the improvement of the RMS quality it is possible to use additive, multiplicative or maximin resulting indicators $[3,6]$.

Additive indicator is the sum of weighted normalized partial indicators of the SMR quality improvement indicators $\left(\Pi_{q}\right)$ and has the form

$$
\Pi_{q}=\sum_{i=1}^{m} \alpha_{i} q_{i},
$$

where $\alpha_{i}$ is the factor of the relative importance of the direction of the quality improvement of the SMR of the TS electrical equipment; $q_{i}$ is the actual value of the requirements realization of improving the quality of the SMR of the TS electrical equipment; $0 \leq \Pi_{q} \leq 1$, $0 \leq \alpha_{i} \leq 1, \sum_{i=1}^{m} \alpha_{i}=1$.

The higher $\Pi_{q}$, the more it affects the quality improvement of the system operation; $\sum_{i=1}^{m} \alpha_{i} q_{i}=1 ; \alpha_{i}>0$; $i=1, m$.

Multiplicative indicator is produced by multiplying partial indicators taking into account their weight factors and has the form

$$
\Pi_{q}=\prod_{i}^{m} q_{i}^{a_{i}},
$$

where $q_{i}$ and $\alpha_{i}$ have the same sense as in the additive indicator. 
Table 1

Map of the quality assessment of the SMR of the TS electrical equipment

\begin{tabular}{|c|c|c|}
\hline Components of steps (methods) of examination & Assessment variants & \begin{tabular}{|l|}
$\begin{array}{l}\text { Assessment } \\
\text { directions }\end{array}$ \\
\end{tabular} \\
\hline $\begin{array}{l}\text { 1. The scientific significance of the adopted strategy of the } \\
\text { SMR of the TS electrical equipment }\end{array}$ & $\begin{array}{l}\text { 1. Extremely high } \\
\text { 2. Much } \\
\text { 3. Not high } \\
\text { 4. Uncertain (now) } \\
\text { 5. Absent }\end{array}$ & $\begin{array}{l}\text { Technical } \\
\text { Economic } \\
\text { Organizational }\end{array}$ \\
\hline 2. The practical significance of the adopted service strategy & $\begin{array}{l}\text { 1. Extremely high } \\
\text { 2. Much } \\
\text { 3. Not high } \\
\text { 4. Uncertain (now) } \\
\text { 5. Absent }\end{array}$ & \\
\hline $\begin{array}{l}\text { 3. The scientific novelty, originality of the adopted service } \\
\text { strategy }\end{array}$ & $\begin{array}{l}\text { 1. No analogues } \\
\text { 2. There are no analogues in the country, there are } \\
\text { abroad } \\
\text { 3. There are no analogues abroad, there are in the } \\
\text { country } \\
\text { 4. There is evidence of some domestic and foreign } \\
\text { analogues } \\
\text { 5. Scientific novelty missing }\end{array}$ & \\
\hline $\begin{array}{l}\text { 4. The methods and ways to achieve the goal of improving the } \\
\text { quality of the SMR }\end{array}$ & $\begin{array}{l}\text { 1. New } \\
\text { 2. Modern } \\
\text { 3. Traditional } \\
\text { 4. Obsolete } \\
\text { 5. Inadequate } \\
\end{array}$ & \\
\hline $\begin{array}{l}\text { 5. The potential of executors of the SMR of the TS electrical } \\
\text { equipment }\end{array}$ & $\begin{array}{l}\text { 1. Sufficient } \\
\text { 2. The lack in the part of scientific support } \\
\text { (experience) } \\
\text { 3. Insufficient in terms of material and technical } \\
\text { base } \\
\text { 4. Lack of in terms of experience of working team } \\
\text { personnel } \\
\text { 5. Insufficient data to assess }\end{array}$ & \\
\hline $\begin{array}{l}\text { 6. The term of the carrying out works of the SMR of the TS } \\
\text { electrical equipment }\end{array}$ & $\begin{array}{l}\text { 1. Real } \\
\text { 2. Overvalued } \\
\text { 3. Reduced } \\
\text { 4. The data sufficient to assess } \\
\end{array}$ & \\
\hline $\begin{array}{l}\text { 7. The cost of work (funding) of the SMR of the TS electrical } \\
\text { equipment }\end{array}$ & $\begin{array}{l}\text { 1. Acceptable } \\
\text { 2. Overstated } \\
\text { 3. Dropped } \\
\text { 4. The data sufficient to assess }\end{array}$ & \\
\hline $\begin{array}{l}\text { 8. Recommendation on priority measures and works to } \\
\text { improve the quality of the SMR of the TS electrical equipment }\end{array}$ & $\begin{array}{l}\text { 1. Events (work) of primary importance } \\
\text { 2. Measures (work) of high importance } \\
\text { 3. Measures (work) are of interest } \\
\text { 4. Measures (work) are of negligible interest but } \\
\text { deserve support if there are sufficient assets } \\
\text { 5. Measures (work) do not deserve support }\end{array}$ & \\
\hline 9. Operation reliability increase of the TS power equipment & $\begin{array}{l}\text { 1. Very high } \\
\text { 2. Significant } \\
\text { 3. Low } \\
\text { 4. Undefined (now) } \\
\text { 5. Missing }\end{array}$ & \\
\hline 10. Check of the efficiency and quality of the SMR & $\begin{array}{l}\text { 1. Very high } \\
\text { 2. Significant } \\
\text { 3. Low } \\
\text { 4. Undefined (now) } \\
\text { 5. Missing }\end{array}$ & \\
\hline Other........................................ & & \\
\hline
\end{tabular}

Scale of correspondence of scoring, linguistic and interval estimations

\begin{tabular}{|c|c|c|}
\hline Scoring estimation & Linguistic estimation & Interval estimation \\
\hline $5-$ Excellent & (B) Fully satisfies the requirements & $0.9-1$ \\
\hline $4-$ Good & (BC) Almost satisfies & $0.7-0.9$ \\
\hline $3-$ Satisfactory & (C) Satisfies mostly & $0.5-0.7$ \\
\hline $2-$ Poor & (HC) Not satisfying & $0.3-0.5$ \\
\hline $1-$ Completely unsatisfactory & (H) Fully not satisfying & $0-0.3$ \\
\hline
\end{tabular}

Table 2 
Maximin indicator. In some cases it is quite difficult to substantiate or to apply the type of the resulting target function. In such cases, a possible simple way of solving the problem is to use the maximin indicator. In this case, the rule of choosing the optimal SMR of the TS has the form

$$
\max (S \in M) \min (1 \leq i \leq m)\left\{\begin{array}{l}
q_{1}^{a_{1}}(S), \ldots, q_{i}^{a_{i}}(S), \\
\ldots, q_{m}^{a_{m}}(S)
\end{array}\right\} .
$$

The maximin indicator of the SMR quality improvement guarantees the best (maximal) value of the worst (lowest) from partial quality indicators.

The material of the research. Scientific results obtaining. However, a large number of indicators of the requirements of improving the quality of the SMR of the Ts electrical equipment may cause loss of objectivity of determining the importance factors $\alpha_{i}$. So, a promising way to solve this problem is to define the integral indicator of quality $\left(I_{q}\right)$ of the SMR taking into account factors indicators importance by directions, methods and stages of the quality improvement of the SMR of the TS electrical equipment.

To determine the integral indicator of quality of the SMR of the TS electrical equipment taking into account the considered conditions and (1) the author firstly proposed the following expression:

$$
I_{q}=\sum_{i=1}^{n} \alpha_{i} \cdot \sum_{k=1}^{m} \alpha_{k} \cdot \sum_{j=1}^{h} \alpha_{j} q_{i k j}=\sum_{i=1}^{n} \alpha_{i} \cdot q_{i}+\sum_{k=1}^{m} \alpha_{k} \cdot q_{k}+\sum_{j=1}^{h} \alpha_{j} \cdot q_{j}
$$

where $\sum_{i=1}^{n} \alpha_{i}=1, \sum_{k=1}^{m} \alpha_{k}=1, \sum_{j=1}^{h} \alpha_{j}=1$ are the factors of relatively importance of directions, methods and stages of the service system quality, respectively; $q_{i k j}$ is the actual value of indicators of the SMR quality improvement level requirements realization for the TS electrical equipment by directions, methods and stages. Such a indicator of the SMR quality estimation is absent in the Standard [7].

Under the proposed elements of the definition of the integrated indicator of the SMR of the TS electrical equipment (4), we build a matrix of a system quality (see Table 3) taking into account steps (methods), directions to increase the service quality of the TS electrical equipment (see Table 1).

Based on the relationships of quality matrix components of the SMR given in Table 2 we form expressions for integrated system of system quality indicators by directions and stages for equipment (1, $2 \ldots N)$ and the system as a whole, according to the formulas (1) and (4):

1. $I_{q 111}=q_{111} \cdot \alpha_{111}$ is the integral indicator of the SMR quality at the service of the equipment 1 of the TS at the condition of the realization of the quality improvement requirements level by the stages 1 and technical direction

2. $I_{q 22}=q_{221} \cdot \alpha_{221}+q_{222} \cdot \alpha_{222}+q_{223} \cdot \alpha_{223}$ is the integral indicator of the SMR quality at the service of the equipment 2 of the TS at the condition of the realization of the quality improvement requirements level by the stage 2 and technical, economic and organization directions.

3. $I_{q N}=q_{1 n 1} \cdot \alpha_{1 n 1}+\ldots+q_{m n 3} \cdot \alpha_{m n 3}$ is the integral indicator of the SMR quality at the service of the equipment $N$ of the TS at the condition of the realization of the quality improvement requirements level by the stages $1 \div M$ and technical, economic and organization directions.

4. $I_{q . S M R}=I_{q 1} \cdot \alpha_{e q .1}+I_{q 2} \cdot \alpha_{e q .2}+\ldots+I_{\text {s } N} \times$ $\times \alpha_{e q . N}$ is the integral indicator of the SMR quality at the service of the equipment $1 \div N$ of the TS at the condition of the realization of the quality improvement requirements level by the stages $1 \div M$ and technical, economic and organization directions.

Table 3

\begin{tabular}{|c|c|c|c|c|c|c|c|c|c|c|}
\hline \multirow{4}{*}{$\begin{array}{l}\text { Stages of the quality } \\
\text { improvement of the } \\
\text { SMR of the TS }\end{array}$} & \multicolumn{3}{|c|}{ Equipment 1} & \multicolumn{3}{|c|}{ Equipment 2} & $\ldots \ldots$ & \multicolumn{3}{|c|}{ Equipment $N$} \\
\hline & \multirow{2}{*}{\multicolumn{3}{|c|}{$\begin{array}{c}\text { Directions of the quality } \\
\text { improvement of the SMR of } \\
\text { equipment } 1\end{array}$}} & \multirow{2}{*}{\multicolumn{3}{|c|}{$\begin{array}{c}\text { Directions of the quality } \\
\text { improvement of the SMR of } \\
\text { equipment } 2\end{array}$}} & & \multirow{2}{*}{\multicolumn{3}{|c|}{$\begin{array}{c}\text { Directions of the quality } \\
\text { improvement of the SMR of } \\
\text { equipment } N \\
\text { On0 }\end{array}$}} \\
\hline & & & & & & & $\ldots \ldots$ & & & \\
\hline & 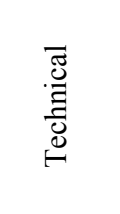 & 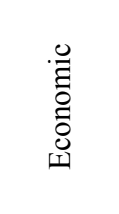 & 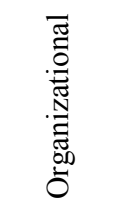 & \multicolumn{2}{|r|}{ 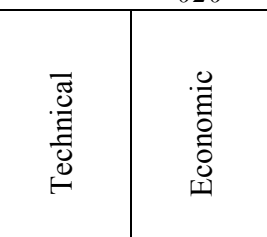 } & 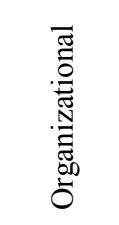 & & 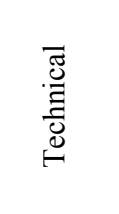 & 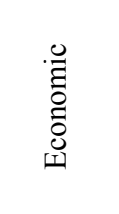 & 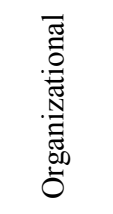 \\
\hline $\begin{array}{c}1 . \\
(\mathbf{1 0 0})\end{array}$ & $I_{q}(111)$ & $I_{q}(112)$ & $I_{q}(113)$ & $I_{q}(121)$ & $I_{q}(122)$ & $I_{q}(123)$ & & $I_{q}(\ln 1)$ & $I_{q}(\ln 2)$ & $I_{q}(\ln 3)$ \\
\hline $\begin{array}{c}2 . \\
(200)\end{array}$ & $I_{q}(211)$ & $I_{q}(212)$ & $I_{q}(213)$ & $I_{q}(221)$ & $I_{q}(222)$ & $I_{q}(223)$ & & $I_{q}(2 n 1)$ & $I_{q}(2 n 2)$ & $I_{q}(2 n 3)$ \\
\hline$\cdots \cdots$ & $\cdots \cdots$ & $\cdots \cdots$ & $\cdots \cdots$ & $\cdots \cdots$ & $\cdots \cdots$ & $\cdots \cdots$ & & $\cdots \cdots$ & $\cdots \cdots$ & $\cdots \cdots$ \\
\hline $\begin{array}{c}M . \\
(\mathbf{M 0 0})\end{array}$ & $I_{q}(m 11)$ & $I_{q}(m 12)$ & $I_{q}(m 13)$ & $I_{q}(m 21)$ & $I_{q}(m 22)$ & $I_{q}(m 23)$ & & $I_{q}(m n 1)$ & $I_{q}(m n 2)$ & $I_{q}(m n 3)$ \\
\hline
\end{tabular}

Quality matrix of the SMR of the TS electrical equipment 
It can be seen that in the correspondence with formed expressions it is possible to calculate integral quality indicators of the SMR at service:

- equipment $1 \div N$ of the TS by any direction and selected stage;

- equipment $1 \div N$ of the TS by all directions and selected stage;

- equipment $1 \div N$ of the TS by all directions and stages;

- SMR of the TS electrical equipment by all stages and directions $-111 \div m n 3$ (see Table 1 ).

Let's consider possible variants of the expert data representation and corresponding techniques of the calculation of the quantitative integral indicator of the quality improvement level of the SMR of the TS power electrical equipment $[3,8]$ :

1. The degree of implementation of each requirement of the quality improvement of the SMR is defined as: the requirement fulfilled $q_{i}=1$; the requirement is not fulfilled $q_{i}=0, i=1, m$. When the degree of fulfillment is determined by the importance of each requirement, integral index of quality assessment is estimated by expressions (1) and (4).

2. The degree of evaluation in assessing the requirements by point scale (see Table 2). For example, by the most popular five-point scale: $b_{i}=5$ - excellent; $b_{i}=4$ - good; $b_{i}=3$ - satisfactory; $b_{j}=2$ - unsatisfactory; $b_{j}=1-$ completely unsatisfactory.

For estimation (prediction) of the quality of the SMR the scoring system is written as follows: excellent the quality system fully meets the requirements; good almost satisfying; satisfactorily - mainly satisfies; unsatisfactory - not pleased; completely unsatisfactory is not fully satisfying.

When the degree of fulfillment of requirements for assessment under point scale is determined by the importance of each requirement $a_{i}$, then the index of the assessment the level of quality improvement of the SMR is determined by the formula

$$
B_{q}=\sum_{j=1}^{m} a_{j} b_{j}
$$

where $1 \leq B_{q} \leq 5,0 \leq a_{j} \leq 1, \sum_{j=1}^{m} a_{j}=1$.

Very often at the point scale assessment of the level of requirements execution it is convenient to have the final assessment in a scale from 0 to $1\left(0<I_{q}<1\right)$. In this connection, we will form the scale of matching: $B_{q}=I_{q}$, $b_{j}=q_{j}, j=1, \bar{m}$.

The calculation of the integral indicator of the assessment the level of quality improvement of the SMR is performed in accordance with (1) and (4).

3. Calculation of the indicator of the SMR quality improvement by using the linguistic variable.

For example, linguistic variable "Quality indicator of the SMR» is defined on a universal set of options $u_{j} ; i=1, \bar{n}$. The level of the indicator will be assessed by term B, BC, C, NA, H presented in Table 2.

Let by the expert way the membership function of belonging of requirements for the SMR to a given level of quality $\mu\left(u_{i j}\right)$ are obtained. Then, using the expressions (4), (5), the integral indicator of the quality of the SMR of electrical railways power supply can be obtained

$$
B_{q}=\sum_{j=1}^{m} a_{j} \sum_{b_{j}=1}^{5} b_{j} \mu\left(u_{i} b_{i}\right) .
$$

Consider the problem of dependence of operational reliability of electrical power equipment of the TS on the SMR quality. The long experience of operating of the equipment of the TS confirms that the quality of the SMR influences on the reliability of the equipment as at the sudden failure and at a gradual accumulation of failures. In this regard, the overall probability of failure of equipment can be expressed as

$$
P(t)=P_{k}(t) \cdot P_{m}(t)
$$

where $P_{k}(t)$ is the probability of failure of electrical equipment of the TS, which is conditioned by the presence of elements of equipment failure which are sudden and can be removed to improve the quality of the SMR; $P_{m}(t)$ is the probability of failure of electrical equipment of the TS with the gradual accumulation of failures of equipment that can be prevented to improve the quality of the SMR by reducing the speed of the parameter that determines the operation ability of electrical equipment.

To calculate $P(t)$ in the first approximation it is possible to take the normal distribution law for the uptime operation assessment [2]

$$
P(t)=\frac{1}{\sigma \sqrt{2 \pi}} \int_{0}^{\infty} e^{-\frac{(x-\bar{x})^{2}}{2 \sigma^{2} d x}},
$$

where $\sigma$ is the root-mean-square deviation of the parameter; $x$ is the measured value of the parameter; $\bar{x}$ is the average value of the parameter (mathematical expectation).

$$
\begin{gathered}
\bar{x}=\frac{\sum_{i=1}^{n} x_{i}}{n}, \\
\sigma=\sqrt{\frac{\sum_{i=1}^{n}(x-\bar{x})^{2}}{n-1},}
\end{gathered}
$$

where $x_{i}$ is the measured value of the parameter at the $i$-th step; $n$ is the number of measurements of the parameter.

Analysis of the obtained calculation expressions permits to suggest that at the decrease in the speed of change of the measured value $x_{i}$ on the $i$-th step during operation by improving the quality of of the SMR of the TS electrical equipment the root-mean-square deviation of the parameter $\sigma$ will also be reduced, and the probability $P(t)$ of failure-free operation $\mathrm{f}$ the TS electrical equipment will increase.

Conclusions. The developed technique and the method of assessing the quality of the SMR of the TS electrical equipment allow: to respond quickly to changes in operating conditions of electrical power equipment of the TS; to determine the most effective strategies of the SMR of the TS electrical equipment under uncertainty functioning of power supply distance; to set (simulate) the 
various operating conditions of the equipment of the TS to select the optimal variant of service and achieve the required level of quality of the SMR; to check state of the improvement of the system; to determine the level of actual integrated indicator of the system quality.

In the paper the author firstly proposes: a formalized version of a document of the assessment of the quality of the electrical power equipment of the TS service by experts; an expression to determine the integral indicator of quality of the SMR of the power electrical equipment of the TS, which is absent in the Standard of the SMR; a matrix of the quality of the system based on stages (methods) and ways to increase service quality of electrical power control systems. This method allows you to perform expert assessment of the service system and predict and choose a rational option of the quality improvement of the SMR of the power electrical equipment of the TS taking into account not only technical but also organizational, legal, financial and economic measures.

\section{REFERENCES}

1. Rassalsky A.N., Sakhno A.A., Konogray S.P., Spitsa A.G., Guk A.A. The basic principles of continuous monitoring of high-voltage oil-filled electrical isolation condenser type under operating voltage. Elektromekhanichni $i$ enerhozberihaiuchi systemy - Electromechanical and energy saving systems, 2009, no.2, pp. 53-55. (Rus).

2. Matusevych O.O. Udoskonalennia metodolohii systemy tekhnichnoho obsluhovuvannia i remontu tiahovykh pidstantsii : monohrafiia [Improving the system of maintenance and repair of traction substations: Monograph]. Dnipropetrovsk, Dnipropetrovsk National University of Railway Transport named after Academician V. Lazaryan Publ., 2015. 295 p. (Ukr).
3. Pankow L.A., Petrovsky A.M., Schneiderman N.V. Organizatsiia ekspertizy $i$ analiz ekspertnoi informatsii [Organization of examination and analysis of expert information]. Moscow, Nauka Publ., 1984. 214 p. (Rus).

4. Kruglov V.V. Nechetkaia logika i iskusstvennye seti [Fuzzy logic and artificial networks]. Moscow, Fizmatlit Publ., 2001. 221 p. (Rus).

5. Borisov A.N., Krumberg O.A., Fedorov I.P. Priniatie resheniia na osnove nechetkikh modelei: primery ispol'zovaniia [Making a decision based on fuzzy models usage examples]. Riga, Znanie Publ., 1990. 184 p. (Rus).

6. Matusevych O.O. The method of reliability estimation of the automated control system functioning of traction power supply of electric transport. Nauka ta prohres transportu. Visnyk Dnipropetrovskoho natsionalnoho universytetu zaliznychnoho transportu - Science and Transport Progress. Bulletin of Dnipropetrovsk National University of Railway Transport, 2009, no.28, pp. 42-44. (Ukr).

7. GOST 18322-78. Sistema tekhnicheskogo obsluzhivaniia $i$ remonta tekhniki. Terminy i opredeleniia [State Standart 1832278. System maintenance and repair of equipment. Terms and definitions]. Moscow, Standartinform, 2007. 12 p. (Rus).

8. Matusevych O.O. Methods of improving the reliability of the control system traction power supply of electric transport based on an expert information. Nauka ta prohres transportu. Visnyk Dnipropetrovskoho natsionalnoho universytetu zaliznychnoho transportu - Science and Transport Progress. Bulletin of Dnipropetrovsk National University of Railway Transport, 2009, no.26, pp. 63-66. (Ukr).

Received 30.11.2015

O.O. Matusevych, Candidate of Technical Science, Associate

Professor,

Dnipropetrovsk National University of Railway Transport named after academician V. Lazaryan,

2, Lazaryana Str., Dnipropetrovsk, 49069, Ukraine.

phone+380676367851, e-mail: al_m0452@meta.ua

How to cite this article:

Matusevych O.O. Methodology of determination of quality index of maintenance service system of power equipment of traction substations. Electrical engineering \& electromechanics, 2016, no.1, pp. 59-64. doi: 10.20998/2074272X.2016.1.11. 